\title{
Batak Women's Reproductive Health Rights in Determining the Number of Children and Joining the KB Program
}

\author{
Esra Simanjuntak ${ }^{1}$, Sri Rahayu Sanusi ${ }^{2}$, Asfriyati $^{3}$ \\ 1,2,3 Faculty of Public Health, Universitas Sumatera Utara, Medan, Indonesia \\ E-mail: esrasimanjuntak37@gmail.com
}

\begin{abstract}
:
Women's rights based on a patriarchal system which questioned the different biological conditions of women and men are the will of nature (nature), so things such as destiny and nature cannot be changed. Reproductive health is a state of perfect health both physically, mentally and socially and is not merely free from disease or disability in all aspects related to the reproductive system, its functions and processes. Reproductive health problems that occurred in Muara District in 2018, the total coverage of Ante Natal Care visits was 91 out of 299 pregnant women (30.43\%). The achievement of use of contraception in 2018 out of 3476 the number of fertile age couples was 1150 people (33.08\%) who used family planning and the choice of delivery assistance chosen by the community by a dukun berakak (sibaso). This study aims to explore in depth the perceptions of women's experiences in obtaining the right to determine the number of children and the right to attend the family planning program. This research is a qualitative research with a phenomenological approach. Sampling in this study was conducted by purposive sampling technique. From the suitability and adequacy of the data obtained, there were six informants who participated in this study. The main informant was a Batak woman. Data was obtained through in-depth interviews supplemented with field notes. The results showed that there were a number of women's reproductive health rights that had not yet been fulfilled, namely the right to determine the number of children and birth spacing and the right to attend the KB program. Patriarchal culture influences the position of women in society, women do not know their reproductive health rights. Researcher's suggestion in this study is that health workers have an important role in improving the degree of reproductive health, it is necessary to conduct cross-program and cross-sectoral collaboration with local community leaders to promote women's reproductive rights, because the community is easier to accept input and opinions given by the king custom.
\end{abstract}

Keywords:

reproductive health rights; batak women; $K B$

\section{Introduction}

Health is a very important element of the quality of life in national development. The national health system has established that the goal of health development is to increase awareness, willingness, and ability to live healthy for everyone so that a high degree of public health can be realized - high human resources, as an investment for socially and economically productive development-Health Law No. 36 of 2009. (Hasibuan, 2020).

Reproductive health is an important component for male and female health. The condition of the disease in women is more associated with the function and ability to reproduce and social pressure due to gender issues. Every human being is born with individual rights attached to each individual. This right can only be guaranteed by emphasizing the obligation of the community and the state to ensure the freedom and opportunities of its citizens to obtain freedom of human rights. Thinking about reproductive rights is a development of the concept of human rights. A concept that developed as a form of reaction 
to a view that discusses the rate of population growth with the level of social welfare. Reproductive rights are essentially related to gender relations which are still lame, differences in the killing of rights between women and men still occur. The progress of time does not erode gender disparity. Women are bound by cultural values inherent in traditional society. Their reproductive function which played only in the domestic sphere makes women more ordinary with various obligations, for example as a mother and wife, must or must educate children, manage the household, accompany and serve their husbands, this makes the position of women limited and restricted. Thus, the position of these women can be manipulated and used to gain benefits from other parties, especially men.

The global issues of women's reproductive health are triggered by various social problems that exist in a country. In developing countries, including Indonesia, women's health problems are still dominated because of poverty, women's social values or low social status, women's discrimination problems in various areas due to gender inequality, violence against women, health care for women who do not receive attention during pregnancy, childbirth and to improve, and there are still many women who do not have the opportunity to continue their education to higher education (Asfiyanti, 2016).

Muara District is a sub-district located in North Tapanuli Regency, which is on the edge of Lake Toba with the majority of the population being Bataks. The Batak community in the Muara area still upholds the culture of their ancestors ranging from the family as the smallest unit, to the community as a whole which is inherited in daily life. Batak traditions governed by adat include birth ceremonies, marriages, drum party ceremonies, the distribution of inheritance, ceremonies for death and burial, ceremonial excavation of ancestral bones, and ceremonies of erecting or inaugurating monuments of clans or ancestors. The Batak community kinship system is a patrilineal system that follows the father's lineage. Male bloodlines can only be passed down by boys, and will go extinct or stop there if there is no son in the family.

In Muara District there is a Community Health Center (PUSKESMAS) which covers a work area of fifteen villages, and in each village there is a Village Maternity Post (Polindes). Based on the PWS-KIA Muara Health Center Report in 2018, the coverage of K1 visits was 155 out of 299 pregnant women (38.46\%) while on K4 visits decreased to 91 from 299 pregnant women (30.43\%). The achievement of use of contraception in 2018 out of 3476 the number of fertile age couples (PUS) was 1150 people (33.08\%) using family planning.

The influence of culture on public health status cannot be ignored, health is an integral part of culture. The results of 2012 health ethnography research in 12 ethnic groups in Indonesia show that maternal and child health problems related to health culture are very alarming. The need to keep working hard until approaching childbirth for pregnant women is also very dangerous for both the mother and fetus. The purpose of this study is to explore in depth about the perceptions of women's experiences in obtaining the right to determine the number of children and the right to attend the family planning program.

\section{Research Methods}

The research method carried out to determine the condition of women's reproductive rights is qualitative with a phenomenological approach that has a women's perspective. This research was carried out in Hutaginjang Village, Muara Subdistrict, North Tapanuli Regency, which began by recording married women with more than 4 children and with less 
socioeconomic conditions and then selected according to the researcher's objectives. Determination of location in the working area of the Muara Health Center because of the available data that in this region there are still many families who have children more than two people and the low number of family planning use is compared with other districts in North Apanuli regency, besides that most women in the region must working as a farmer or trader with a husband who does not fulfill his role as breadwinner.

Participant recruitment was carried out using a purposive sampling approach that is in accordance with the research objectives and is sufficiently representative. In this study, the participants were Batak tribe women who were married and had children who lived in the village of Hutaginjang, together with Muara, North Tapanuli Regency.

Data collection procedures through midwives coordinating the Muara Health Center, researchers met the participants with established criteria. The researcher then gave informed consent to be able to participate in this study. After that researchers conducted in-depth interviews. The data analysis technique used in this study is by using a qualitative approach with 3 analysis activities in the Flow model which is also called the Miles and Huberman Models.

\section{Discussion}

In the Batak traditional culture, women have a low position compared to men. Patriarchal culture in the Batak tribe makes women unable to freely make decisions or give their opinions. This patriarchal culture also positions women unable to regulate the number of children and the birth of their children. The Batak tradition still believes that boys will be the successors to the lineage who will carry on the father's clan.

\subsection{Right to Determine Number and Distance of Child Birth}

Many factors affect women in making decisions about pregnancy. The results found that there were still differences in the acceptance of children born with male and female genders. The average informant in this study had four to eight children. When the researchers asked why they wanted to have many children, the answers from the informants varied, some said because they did not participate in the family planning program so that pregnancy was not planned, there were those who stated that they still had one son and there were those who said that their husbands who wanted to have many a boy to become a family successor.

From Mrs. Sombombing's experience in determining the number and distance of child births, the principle must be to have a son. Before in their family was blessed by a son the husband of this informant was not nice to the informant, her husband was often not at home going to lapo tuak and returning late at night, but when the informant gave birth to her fourth child a husband of her husband turned into it is better for him, following the statement of the informant:

"Well ... if we are clear Bataks there is a difference. Boys are the successor to our family, if the daughter is the same person. That's us, the first child until our third child is his daughter, so I'm sad why aren't God being loved by us boys, my husband and my parents-in-law have started making a fuss about blaming boys. Until my husband became cold with me, it didn't work, went to Lapo to drink wine until morning, but after a boy we changed he was better" (Mrs. Sihombing, 32 yrs). 
It is very important to have a son in Batak custom, as the successor to the family clan. If the family does not have a son, the big family will try hard to get a son. In Batak custom there is the term chef do hamoraoun son au, which means that boys are the most valuable treasure for a family. This was experienced by one of the informants who still had one son. The informant stated that making a decision to determine the number of children was mutually agreed upon, but still the husband did not allow the informant to participate in the family planning program because he wanted to increase the number of sons. Male, the following is the informant's statement:

"The same is true, but my husband is more often told to get pregnant again, who knows there can be a boy" (Mrs. Simaremare, 35 years).

The difference in the values of boys and girls was also revealed by an adat king in Muara. He stated that the boy's presence was very important in the Batak family. In addition to being the successor to the family clan, boys also become heirs of their parents. Girls will be given to other people's families and become other people's families, while boys will be successors to the family, following the informant's statement:

If it is the boy who will continue the father's clan, but the girl who will be the same person, we will not also inherit his parents' inheritance for his son, while as the grandest grandson of his grandfather, he will have the same wealth. If a woman gets wealth from her husband, right? "(Simatupang, $72 \mathrm{yrs)}$

Judika N Sianturi (2017) states that children are the most awaited gift of God, especially in the Toba Batak community. Boys are preferred because boys are the bearers of the clan and successors of offspring in the families of the Toba Batak community. Children are the pride of the Toba Batak community. Children in the Toba community are also an addition to the sahala (authority) for parents, so that in the Toba Batak community do not have children, especially boys will feel like there is something lacking because if they do not have sons, the family's lineage will become extinct.

Making decisions related to determining the number of children and birth spacing of Batak girls does not have autonomy (authority) over themselves, decision making in determining the number and distance of children is dominated by the husband's decision. Batak tribal women are not free to make decisions in determining how many children, when to get pregnant and determine the birth spacing of their children, because the patriarchal value in the Batak tribe makes male power higher than women in the family, as experienced by Mrs.Ompusunggu who has had enough when they have two children, but her husband wants to have many sons, the following is what the informant said:

"If I were my first child, a boy's second daughter, I think it would be right, I'm happy. But yes that's my husband likes to have many boys. Yes, the invitation is followed" (Mrs.Ompusunggu, 32 years).

The attainment of women's autonomy (authority) in determining the number of children and the birth spacing of children is also experienced by Balinese women. Autonomy of Balinese women in Pemaron village in making decisions on their reproductive rights, the determination of the number of children in the family is still uncertain in number, because it is incomplete if there are only girls, the presence of boys in the tradition of Balinese society is the pride of the family. Likewise in the spacing of child births it can be seen that the mother / informant is still asking for approval from her husband and also on the use of contraceptives 
that will be used by the mother, all of which will have an impact on women's physical and mental health. As for the timing of having children, when observed by Balinese women in Pemaron village, they show resignation and acceptance, what their husbands say about their reproductive rights. All that is seen is the dominance of the husband, due to the patrilineal kinship system prevailing in the tradition of a strong Balinese society, boys as the successors of his family's purusa. Also in decision making, related to power and authority possessed by men (Komang, 2017).

Two informants revealed that having children and arranging child birth spacing were not determined, because the informants did not follow the family planning program and did not use contraception, the informant's statement follows:

"Ehe ... I don't even know how to do it, well it goes as usual." Bah my husband asked to have that kind of child. If I want more and more of my four children, I will just close it immediately, but my husband is not allowed "(Mrs. Situmorang, 37 years).

"If that's not what we have planned, well, it's fortune to get pregnant. I don't use KB, "(Mrs. Nababan, 32 years).

One other informant stated that having a child and arranging the birth spacing of her decision together with her husband, included the following statement:

"Ialah, decision together. He never forced his will with me" (Mrs. Rajagukguk, 32 years).

The inability of a wife to make a decision in determining the number of children felt by Batak women in the Muara area because in Batada culture, women must submit to their husbands and listen to their husbands' words. Parents also always advise Batak women who will marry to respect their husbands with all their strengths and weaknesses. Very visible patriarchal culture in Batak culture that makes women bound to their culture.

Lack of women's power to make decisions in determining and managing the number of children is supported by research conducted by Asmi (2004), although women in the household have a large role in the economic field, but they are unable to make decisions relating to their reproductive rights, especially in determining the number of children. This finding also proves the truth of the analysis offered by socialist feminists, who state that women remain subordinated despite having a large role in economic resources as long as patriarchal culture is still dominant (Meutia, 2008).

\subsection{Right to Join the Family Planning Program}

Referring to Law Number 52 of 2009 concerning population development and family development, family planning is defined as an effort to regulate child birth, spacing and ideal delivery, regulating pregnancy, through promotion, protection and assistance in accordance with reproductive rights to create quality families. The family planning program is a program intended to help couples and individuals achieve their reproductive goals, prevent unwanted pregnancies and reduce the incidence of high risk pregnancies, morbidity and death. Very often in the family planning program fertile age couples do not take the right decision to follow. In this study to participate in the family planning program, the informant did not have the right to decide for himself, even though the informant wanted to attend the face-to-face family program that could not be followed because the husband would not allow it. The decision to join the family planning program is in men. The husband of the informant does 
not allow to join the family planning program on the grounds that the husband is more concerned with the informant to focus on working in the fields to fulfill their lives, the following is the informant's explanation:

"My husband would rather just work in the field than I go to the midwife to take care of using Kb. I love where my husband is not making a fuss, let me just follow what he wants" (Mrs. Nababan, 35 years).

A different reason was given by the informant Mrs. Situmorang, her husband forbade her to attend the family planning program because her husband was afraid that he would be disturbed during intercourse. The informant's husband considers the contraception to make him uncomfortable. So the informant does not follow the family planning program, the informant does the program naturally and pregnancy often occurs that is not desired by the informant, but the informant still maintains each pregnancy., The following informants say:

"Ehhheeee ... That was not given by my husband I used KB, he said he was afraid that if the relationship would be disturbed. That's why I don't use kb until I now." (Mrs. Situmorang, 37 years).

The same experience experienced by Mrs. Syombing, this informant is also not allowed her husband to participate in family planning programs. Previously the informant used three months injection contraception, but the informant felt the contraception was not suitable for her, her husband complained that his body shape was getting fatter after using a three month injection contraception. Because her husband did not like the changes in her, the informant followed her husband's decision to stop using contraception.

"Where my husband does not like me to use $\mathrm{KB}$, first I use $\mathrm{KB}$ injections for three months, so it's fat I am. My husband was angry because of my fat, kek not suitable I think I also use this KB. So I stop, I'm not anymore "(Mrs. Sihombing, 32 years).

Other informants expressed fear use contraception because of his hard work in the fields, afraid to endanger himself and cause illness in his body. The informant saw his friend becoming very thin and also sick because of using contraceptives, the thing that happened to this informant was because of the informants' low knowledge about contraceptives, following the infomation's statement:

"Ehee dabah ... we do our work in the fields, lifting our heavy weights. People say if their work lifts heavy, the KB can be released. If I take off my KB, it will disturb my kingdom later. While we need money to raise our children" (Mrs.Ompusunggu, 32 years).

While Mrs. Simaremare did not participate in the family planning program because her husband wanted to have a son, even though the informant had used three months of injection contraception before, following the informant's explanation;

"Ehe ... Still one of my sons, not happy I feel. He also spelled my husband, we don't need to be the first, we will add our son, so that there is a friend who is erik, then my first child "(Mrs. Simaremare, 35 years old).

Only one of the six informants who met together with her husband in joining the family planning program. The informant told her husband that she would use contraception and her husband gave a positive response by giving the informant the full decision to make 
the best decision for his family about the family planning program that he was going to follow, along with a statement from the informant:

"KB ... I use injections for three months now, I used to have a pill but it didn't work,... Well, I tell my husband I want to use KB. He said whatever you want. No, he forbade me" (Mrs. Rajagukguk, 32 years)

Suci Rahayu Research (2017) there are several reasons for fertile age couples not participating in family planning programs, such as fear of side effects with a frequency of 34 people or 37.78 percent or 34 people such as weight gain when using contraception, there are 2 women with EFA or equal 2.22 percent who did not get support or approval using contraception. This means that indicators of husband support as a reinforcing factor or factors that determine whether health behavior is supported based on Lawrence Green Health Behavior Theory is not a factor that causes the low use of MKJP in Gunung Terang Village. As a side effect, acceptors are encouraged to return to the family planning service in order to obtain further treatment (Sulistyawati, 2012). In addition to fear of side effects, the reason with the next highest percentage is the perception of other people about the negative issue of using contraception with $21 \mathrm{EFA}$ women or 23.33 percent. The negative issues in question are negative stories about the use of implants, IUDs and sterilizers that they have heard from other people and there are other reasons such as fear of operative action / surgery, want to increase the number of children in the near future and health conditions that do not support the use of contraceptives.

Reproductive health rights are human rights that should have been obtained by the community, especially family planning acceptors $(\mathrm{KB})$ through quality family planning services which are government programs. The right to make decisions in participating in family planning is one of the factors in fulfilling reproductive rights (Trijiwati, 1997). Determination of when, how much and the time interval having children is the rights and responsibilities of the couple and the individual concerned. What is important in the sense of responsibility is freedom from coercion.

The Family Planning Program is one of the national development programs that is very important in order to create a prosperous Indonesian family. Family planning (KB) is an effort to increase awareness and community participation through maturing the age of marriage, birth control, family coaching, improving family welfare to create a happy, prosperous small family. In accordance with the recommendations of the 1994 International Population and Development Conference (ICPD) in Cairo, it was agreed to change the paradigm of the National Family Planning. This change from the concept and implementation of population control programs and fertility reduction to the approach to reproductive health approaches that pay more attention to reproductive rights and development oriented to justice and gender equality (Raihan, 2013).

Based on the 2010-2035 Population Projection of Indonesia, the population of Indonesia during the last 5 years shows increasing. In 2011 Indonesia's population reached 241.99 million people and continued to increase until 2015 to 255.46 million people. One factor that triggers a high population growth is the high birth rate in an area. The number of births that occur in a woman can be influenced by her reproductive period. The longer the reproductive period of a woman, the greater the number of children born. Changes in population can not be separated from the factors that influence it. One of the factors that influence changes in population is fertility. Based on BPS data in the 2010-2035 Indonesian Population Projection, the Total Fertility Rate (TFR) by 2015 TFR was 2.4. 
Women in the study area still cannot decide for themselves the number and distance of their children and are expected to fulfill the wishes of their husband's family. Determination of the number and distance of children depends on the motivation of the informants to do so. The number of children is very much determined by the background of the informant's family and her husband so that they make decisions about the number of family members more than the previous generation. Based on the results of the study, most informants did not determine the number of children at the beginning of their marriage. They only think about stopping childbirth when the number of boys is in accordance with the desires of the family and feels they are unable to pay for their children's lives with only income as a farmer. The needs of children today are not just daily needs but also for school needs.

This study is in line with research conducted by Suarni (2015) with the results of a study which stated that the occurrence of subordination of girls in families in the Warian Village Baraka District Enrekang District caused by two factors namely nature (nature) and social construction (nurture). In nature, the difference between male and female nature from God Almighty. However, by nature the differences between men and women are determined by the community in their own environment.

A patriarchal culture can lead to the assumption that reproductive health is a woman's problem that results in a lack of participation, concern for men in reproductive health. Family planning is only considered a female problem so there are very few male family planning acceptors. Women, especially informants in the study area, are family planning acceptors, in their view that those who participate in the family planning program are women. The number of children has been agreed upon and determined but with conditional so that women are expected to fulfill it. This is related to the value of children in the Batak community. Daughter is also expected in the family because a son is already present so the husband allows his wife to join the family planning program if he has given birth to a son.

\section{Conclusion}

Women are often valued as being more inferior than men in daily life. Women are considered to be weak creatures so they must be under the control of men. Women often lack the opportunity to take part in social life when compared to men. Phenomenon, reality, and socio-cultural facts as stated show clearly the unequal, unequal, and discriminatory relations of men and women.

Batak women's reproductive rights are not fulfilled, Batak women are still bound by cultural values that exist in the Muara area. Determination of the number and distance of children is not entirely determined solely by women. Women are required to provide successors to their husband's family. Women have the functions of production and reproduction in their families. The decision to join the family planning program depends on the husband's consent. Information related to reproductive health is still lacking. Therefore, health services for pregnant women need to be improved by facilitating their access to health services. 


\section{References}

Burns, A. A., Lovoich, R., Maxwell, J., Shapiro, K. (2000). Pemberdayaan Wanita dalam Bidang Kesehatan, Yogyakarta : Yayasan Essentia Medica.

Fatma, L. (2013). Penegakan Hak Reproduksi Perempuan dalam Kebijakan Keluarga Berencana di Indonesia, Volum 6 (1)

Graafland.N. (1994). Kaum Wanita di Minahasa, dalam Subadio.M.U,Ihromi.T.O.Peranan dan Kedudukan Wanita Indonesia. Yogyakarta, Gadjah Mada University Press.

Hasibuan, S. (2020). Relationship of Family Income and Family Support with Maternal Reference in Pregnant Women in Pantai Cermin BEmONC, Langkat District, 2019. Budapest International Research and Critics Institute-Journal (BIRCI-Journal). P. 486493.

Judika., N., S. (2017) Makna Anak Laki-Laki di Mayarakat Batak Toba. 4(2), 1-14

Komang, S. (2017). Otonomi Perempuan Bali Dalam Pengambilan Keputusan Atas Hak Reproduksi Dalam Keluarga. Universitas Udayana Denpasar

Pratiwi, A., Asfiyati, y. (2016). Seksualitas dan Kesehatan Reproduksi Perempuan, Depok : Raja Grafindo Persada

Raihan, S. (2013). Partisipasi Pria dalam Ber-KB. Jurnal BKKBN

Suarni,. (2015). Subordinasi Anak Perempuan Dalam Keluarga. 3(1), 29-37

Suci, R. (2017). Faktor-faktor Penyebab rendahnya Penggunaan Metode Kontrasepsi Jangka Panjang

Sugiono. (2017) Metode Penelitian Kuantitatif Kualitatif dan R \& D, Bandung : Penerbit Alfabeta.

Sulistyawati, Ari. (2012). Pelayanan Keluarga Berencana. Jakarta: Salemba Medika.

Triwijati, N.K Endah. (1997). Memahami Kekerasan Dalam Rumah Tangga Dan

Menanggulanginya. Jakarta: Program Pasca Sarjana Universitas Indonesia

Yusuf., M. (2014). Metode Penelitian Kuanitatif, Kualitatif dan Peneltian Gabungan Jakarta: Prenadamedia Group

Zulfadli Barus. (2014). Analisis Antropologi Hukum Tentang Pengaruh Nilai-Nilai Budaya Terhadap Budaya Hukum Masyarakat Batak-Toba Terkait Dengan Batas Usia Kawin Menurut Undang-undang Nomor 1 Tahun 1974, Vol. 3 No.2 Mei 